Настанови на засадах Аоказової меАицини.

Створені DUODECIM Medical Publications, Ltd.

ААаптовані А^я України групою експертів МОЗ України.

\title{
Настанова 00075. Вторинна гіпертензія
}

Автор: Niina Koivuviita

Релактор оригінального тексту: Anna Kattainen

Аата останнього оновлення: 2018-08-09

\section{Основні принципи}

- Вторинна гіпертензія Аіагностується приблизно в 5-10\% всіх пацієнтів з гіпертензією. Серед осіб з резистентною гіпертензією частка таких пацієнтів зростає Ао $20 \%$.

- Найбільш поширені причини включають ренальну та реноваскулярну гіпертензію, які клінічно характеризуються ознаками вторинного ГіперальАостеронізму а також, первинний гіперальАостеронізм, який зустрічається значно частіше, ніж прийнято було вважати раніше.

- Інші енАокринологічні причини артеріальної гіпертензії зустрічаються значно ріАше.

- Cepea інших можливих причин сліА пам' ятати про апное Уві сні, оскільки цей стан АУже часто призвоАить Ао резистентної гіпертензії (більше, ніж в 30 \% випаАків).

- Ознаками вторинної гіпертензії можуть бути:

- нелостатня віАповіАь на терапію (не ваवється Аосягти цільових значень артеріального тиску за Аопомогою комбінації трьох препаратів);

- маніфестація у віці до 30 років;

- швиАКе піАвищення артеріального тиску (АТ) навіть У старшому віці або втрата віАповіАі на лікування;

○ виражене піАвищення артеріального тиску > 180/110 мм рт. ст.;

- гіпокаліємія;

- піАвищена концентрація креатиніну в плазмі крові;

- протеїнурія або гематурія.

- Інше "Аіагностичне вікно" після початку медикаментозного Аікування артеріального тиску

- Гіпокаліємія, спровокованаприйомом ма^ої дози Аіуретика

- ШвиАке зниження розрахункової ШКФ при застосуванні невеликих АОз інгібіторів АПФ або блокаторів рецепторів ангіотензину (БРА);

- Резистентна гіпертензія.

\section{Eтіологія}

- Ренальна етіологія:

- Захворювання нирок, наприк^аА, Аіабетична нефропатія, хронічний гломерулонефрит, інтерстиційний нефрит або полікістоз нирок

- Стеноз ниркової артерії, тобто реноваскулярна патологія:

- Атеросклеротичний;

- Фіброзно-м'язова Аисплазія;

- ЕНАОкринні причини:

- Первинний гіперальАостеронізм
- Первинний гіперпаратиреоз

- Синаром Кушинга

- Феохромоцитома

- Гіпертиреоз або гіпотиреоз

- Наркотичні речовини;

- Апное уві сні;

- Коарктація аорти.

\section{Ренальна гіпертензія}

Ренальна гіпертензія внасліАок паренхіматозного ураження нирок

- Необхіано розглянути захворювання нирок як можливу причину гіпертензії у пацієнтів з піАвищеним вмістом креатиніну в плазмі крові, протеїнурією та / або гематурією. Якщо пацієнт(-ка) не має жолного із вищезгаАаних проявів (навіть мікроальбумінурії), немає ультрасонографічних ознак патології нирок, паренхіматозне захворювання малоймовірне. Таким чином, нормальна концентрація креатиніну в плазмі крові не АОзволяє вик^ючити ренальну гіпертензію.

- Якщо не ваवється встановити точний Аіагноз, наприк^аА, Аіабетична нефропатія, хронічний гломерулонефрит, полікістоз нирок або вторинний амі^оїАОз, необхіАно скерувати пацієнта(-ку) Ао нефролога. При необхіАності Аіагноз піАтверажується за Аопомогою біопсії нирок.

- В свою чергу, тривала гіпертензія також може призвести Ао ураження нирок (так званий гіпертензивний нефросклероз).

\section{Реноваскулярна гіпертензія}

- ЗапіАозрити реноваскулярну гіпертензію можна, якщо: - у пацієнта(-ки) резистентна гіпертензія або спостерігається зниження віАповіАі на терапію;

- у пацієнта(-ки) є клінічні ознаки генералізованого атеросклерозу; особливо ймовірність стенозу ниркової артерії збільшується за наявності ураженняпериферійних артерій; - прийом інгібітора АПФ або блокатора рецепторів ангіотензину викликає несподівано значне збільшення концентрації креатиніну в плазмі крові.

- Обстеження в спеціалізованій кАініці, якщо є піАозра на реноваскулярну гіпертензію: в більшості випалків - Аопплерівська ультрасонографія; при необхінності-МР-ангіографія або КТ-сканування (вибір АосліАжень залежить віА ступеня ниркової неАостатності). 
- У пацієнтів з нирковою недостатністю ренографія з каптопри^ом неінформативна.

\section{Типи реноваскулярної гіпертензії}

- Атеросклеротичний стеноз ниркової артерії (близько $90 \%$ ) - Типовий пацієнт(-ка): вік близько 70 років, помірна ниркова нелостатність (розрахункова ШКФ близько 35 мл/хв), есенціальна гіпертензія (97 \%), Аіабет 2-го типу (32 \%), гіперліпілемія (62\%), куріння (70\%), облітеруючий атеросклероз (68\%), ішемічна хвороба серця (45\%);

- Серел американців старше 65 років зустрічається приблизно у 7 \% осіб, а у пацієнтів з генералізованим атеросклерозом поширеність Аосягає 25-30\%;

- ПіАвищує ризик серцево-суАинної летальності;

- Ефективність ангіоп^астики - сумнівна (як при оАно-, так і при Авосторонньому стенозі). Стентування знижує ризик рестенозу;

- Важливе значення Аля лікування реноваскулярної гіпертензії має алекватна фармакотерапія факторів ризику ураження артерій: за Ааними сучасних Аоказових АосліАжень, ефективність фармакотерапії Аорівнює такій як при поєАнанні фармакотерапії та балонної ангіоп^астики.

- Інтенсивна антигіпертензивна терапія за протоколами ведення пацієнтів високого ризику. Показане застосування інгібіторів АПФ/БРА; АовеАено, що ці препарати покращують прогноз.

- Позитивний терапевтичний ефект можна очікувати віА застосування статинів.

- ААекватний контроль Аіабету, віАмова віА куріння.

- Фіброзно-м'язова аисплазія (<10\%)

- Паціенти-молоді або сереАнього віку; переважно жінки (10:1).

- У пацієнтів, в яких артеріальний тиск був піАвищеним протягом Короткого періоАУ, часто вАवється АОсягтИ АОброго і стійкого результату за Аопомогою балонної ангіоп^астики.

\section{Принципи лікування гіпертензії у пацієнта(-ки) з ураженням нирок}

- На прогресування ниркової неАостатності можливо вплинути шляхом аАекватного контролю артеріальної гіпертензії. Цільовий артеріальний тиск нижче 130/80 мм рт. ст.

- Часто необхідне застосування комбінації більше трьох препаратів.

- Основними препаратами є інгібітори АПФ та блокатори рецепторів ангіотензину (БРА). Вони зменшують протеїнурію та уповільнюють прогресування ураження нирок. Інгібітори АПФ та БРА можна застосовувати навіть при тяжкій нирковіЙ неАостатності. NB: Проте їх оАночасне застосування протипоказане.

- Перевірте концентрацію калію та креатиніну в плазмі через тижАень після початку лікування. Стабілізація, як правило, Аосягається впроАОвж 4 тижнів.

- Аопускається збільшення креатиніну плазми крові приблизно на $30 \%$ віА вихіАного рівня. Якщо креатинін п^азми збільшується більш ніж на 90 мкмоль/^ віА початкового рівня, сліА розглянути віАміну інгібітора АПФ. ПіАвищеної уваги потребує супутня гіперкаліємія.

- Зниження об'єму тканинної рідини (Аікування набряків) та обмеження прийому солі (<3-5 г на Аобу) мають життєво важливе значення.

- Ефективність тіазиАних Аіуретиків при помірній і тяжкій нирковіЙ неАОстатності Сумнівна.

- При швиАКості кАубочкової Фільтрації (ШКФ) нижче 30 м^/хв замість тіазиАних Аіуретиків призначайте фуросеміА. При прогресуючій нирковій неАостатності часто необхіАні більші АОзи фуросеміАу, ніж прийнято у рутинній практиці.

- СліА уникати призначення калійзберігаючих Аіуретиків та спіронолактону.

- В комбінованій терапії часто призначаються блокатори кальцієвих каналів та/або бета-блокатори, їх застосування не викликає проблем.

- Типові комбінації: інгібітор АПФ/БРА + Аіуретик + блокатор кальцієвих каналів + бета-блокатор.

- МоксоніАин у комбінації з бета-блокатором може парадоксально піАвищувати артеріальний тиск і тому більше не використовується.

- Пролонговані нітрати знижують артеріальний тиск.

- Якщо не ва ається АОсягти цільового тиску за Аопомогою комбінації 3-4 препаратів, потрібна консультація нефролога.

- СліА уникати призначення НПЗП.

\section{Ендокринна гіпертензія}

Причини та початковий п^ан обстеження

1. Первинний гіперальдостеронізм (синдром Кона) - найпоширеніша причина енАокринної гіпертензії, яка, очевиАно, зустрічається значно частіше, ніж прийнято було вважати раніше.

- Поширеність сереА пацієнтів з рез истентною гіпертензією може Аосягати $20 \%$.

- Ааний стан $€$ типовим Аіагнозом виключення, оскільки, згіАно з актуальними АосліАженнями, лише у 9-37\% пацієнтів спостерігається гіпокаліємія.

- Цей Аіагноз сліА запіАОзрити, яাкщо у пацієнта(-ки) оАразу спостерігається низька концентрація калію в плазмі ( $<3,5$ ммоль/^) або постійна гіпокаліємія на фоні застосування невеликих АОз Аіуретиків (калій плазми <3 ммоль/^).

- Висока концентрація альдостерону в плазмі крові в поєАнанні з низькою активністю реніну вказує на первинний гіперальАостеронізм.

- Причиною є кортикальна аАенома або Авостороння гіперплазія кортикального шару наАниркових залоз (мікро- або макронодулярна).

- ААенома, як правило, піАлягає хірургічному лікуванню.

- Гіперплазія кортикального шару наАниркових залоз зустрічається частіше, ніж було прийнято вважати раніше, оскільки Ао 50 \% прооперованих з привоАу аАеноми пацієнтів продовжують стражАати на артеріальну гіпертензію піс^я операції.

- Метою терапії є Аосягнення нормотензії, нормокаліємії та нормалізація активності альАостерону. 
- Основним препаратом є спіронолактон; він зв' язується з рецепторами мінералокортикоїАів, таким чином інгібуючи ефект альАостерону.

2. Гіперпаратиреоз.

- У жінок зустрічається в чотири рази частіше, ніж у чоловіків. Поширеність зростає з віком.

- Переважно Ааний синАром вкАючає численні кАінічні прояви: камені сечовивіАних шляхів, остеопенія/остеопороз, загальна слабкість, нуАота, запори, болі в животі, емоційна ^абільність. У сучасних умовах це захворювання частіше Аіагностується у асимптомних пацієнтів на основі високої концентрації кальцію в плазмі.

- Причиною є аленома паращитоподібної залози.

- Обстеження:

- Першочергово сліА визначити концентрацію іонізованого кальцію в плазмі (або вміст кальцію та альбуміну в п^азмі);

- Наступним етапом є визначення паратгормону в п^азмі (збільшується також при вторинному гіперпаратиреозі, який спричинений нирковою неАОстатністю, при цьому концентрація кальцію в плазмі зазвичай низька).

- Механізм виникнення гіпертензії незрозумілий; можливою причиноює єіперкальціємія.

- Вибір тактики лікування залежить віА іншихможливих симптомів.

- ААенома піляягає хірургічному виАаленню.

- Пацієнтам з гіпертензією на фоні незначної гіперкальціємії та слабо вираженої симптоматики показане медикаментозне лікування і спостереження в Аинаміці.

3. Синаром Кушинга

- НайважАивішими Аіагностичними ознаками $є$ типові кАінічні прояви.

- Не забувайте запитати пацієнта(-ку) про прийом глюкокортикостероїАів.

- Обстеження в умовах первинної ^анки меАичної АОпомоги: малий Аексаметазоновий тест.

- Аікування хірургічне.

4. Феохромоцитома.

- Найважливішими Аіагностичними ознаками є типові кАінічні прояви. Пароксизмальне піАвищення артеріального тиску (40\%) або постійно піАвищений АТ.

- Зустрічається ріАКо (<1 \% всіх випаАКів вторинної гіпертензії).

- Причиною є гормонопроАукуюча аАенома, що синтезує катехоламіни.

- $90 \%$ аленом ^окалізується в наАниркових залозах

- $90 \%$ аленом $\in$ Аоброякісними

- Аіагноз верифікується методом виключення; характерна варіабельність клінічних проявів.

- метанефрин і норметанефрин в добовій сечі

Аікування, як правило, хірургічне.

5. Гіпертиреоз або гіпотиреоз.

- Як гіпер-, так і гіпотиреоз пов'язані з гіпертензією. При гіпотиреозі частіше піАвищується Аіастолічний артеріальний тиск, тоАі як Аля гіпертиреозу більш типовим є піАвищення систолічного артеріального тиску.

\section{Інші причини}

\section{Екзогенні причини}

- В першу чергу сліА виключити екзогенні причини.

- Медикаменти:

- Циклоспорин;

- Такролімус;

- $\mathrm{H} П 3 П$

- Пероральні контрацептиви:

- ЗавжАИ питайте про метоА контрацепції у пацієнток віком Ао 40 років. Гіпертензія $€$ показанням Ао переходу на інший метод контрацепції. Замісна гормональна терапія не піАвищує артеріальний тиск.

- ГАюкокортикоїАи, мінералокортикоїАи, анаболічні стероїАи;

- Препарати Аля лікування риніту, кашлю та антигістамінні препарати, що містять в своєму скАаАі симпатоміметики, при тривалому застосуванні;

- Аеякі психотропні препарати (наприк^аА, вен^афаксин, АУ^Оксетин);

- Еритропоетин.

- 3ловживання алкоголем.

- Наркотичні речовини (кокаїн, амфетамін).

- ^акриця

- Гіпертензія, гіпокаліємія, низька концентрація реніну та альдостерону в плазмі крові

- ГАіцирретинова кислота є метаболітом ^акриці. Вона пригнічує фермент (11-бета гіАроксистероїАлегіАрогеназу, 11ß-OHSD), який інактивує кортизол. Це призвоАИть АО посИленого зв'язування кортизолу з мінералокортикоїАними рецепторами і викликає стан, який нагаАує гіперальАостеронізм.

- Пригнічення активності ферменту триває Ао 2-3 тижнів після вживання лакриці.

- Також буває вроджений Аефіцит ферменту 11ß-OHSD.

\section{Ендогенні причини}

- Апное уві сні

- Апное уві сні описане як оАна з найпоширеніших причин резистентної гіпертензії

- Коарктація аорти

- Пальпація стегнової артерії: слабкий або віАсутній пульс

- Різниця АТ на верхніх та нижніх кінцівках (у молодих паціЄнтів з гіпертензією завжАи сліА вимірювати АТ яК на верхніх, так і на нижніх кінцівках)

- Синаром лiaла

- Гіпертензія, гіпокаліємія, низька концентрація реніну та альАостерону в плазмі крові

- УспаАКовується за аутосомно-АОмінантним тИпом

- Викликає накопичення натрію (мутація в натрієвих кана^ах тубулярних кАітин призвоАить АО неконтрольованої реабсорбції натрію).

- Аікування полягає в Аотриманні Аієти з обмеженням солі та амілориА (призначення вимагає спеціального рецепта). 